\title{
Sources and Origin of Resistance to Xanthomonas campestris pv. campestris in Brassica Genomes
}

\author{
J. D. Taylor, J. Conway, S. J. Roberts, D. Astley, and J. G. Vicente
}

Horticulture Research International, Wellesbourne, Warwick CV35 9EF, UK.

Accepted for publication 19 September 2001.

ABSTRACT

\begin{abstract}
Taylor, J. D., Conway, J., Roberts, S. J., Astley, D., and Vicente, J. G. 2002. Sources and origin of resistance to Xanthomonas campestris pv. campestris in Brassica genomes. Phytopathology 92:105-111.

Two hundred and seventy-six accessions of mainly Brassica spp. were screened for resistance to Xanthomonas campestris pv. campestris races. In Brassica oleracea (C genome), the majority of accessions were susceptible to all races, but $43 \%$ showed resistance to one or more of the rare races $(2,3,5$, and 6$)$ and a single accession showed partial resistance to races $1,3,5$, and 6 . Further searches for resistance to races 1 and 4 , currently the most important races worldwide, and race 6 , the race with the widest host range, were made in accessions representing the $\mathrm{A}$ and $\mathrm{B}$ genomes. Strong resistance to race 4 was frequent in B. rapa (A genome)
\end{abstract}

and B. napus (AC genome), indicating an A genome origin. Resistance to races 1 and 4 was present in a high proportion of B. nigra (B genome) and $B$. carinata (BC genome) accessions, indicating a $\mathrm{B}$ genome origin. $B$. juncea (AB genome) was the most resistant species, showing either strong resistance to races 1 and 4 or quantitative resistance to all races. Potentially race-nonspecific resistance was also found, but at a lower frequency, in B. rapa, B. nigra, and B. carinata. The combination of racespecific and race-nonspecific resistance could provide durable control of black rot of crucifers.

Additional keywords: black rot of crucifers, disease resistance, pathogen variants.
Black rot of crucifers caused by Xanthomonas campestris pv. campestris (Pammel) Dowson is considered to be one of the most important diseases of crucifers worldwide (30) and is most serious in Brassica oleracea. Control of the disease is difficult and is usually attempted through the use of healthy planting material (seeds and transplants) and the elimination of other potential inoculum sources (infected crop debris and cruciferous weeds). An alternative approach through the development and use of resistant cultivars has long been recognized, but in practice has had only limited success.

Early studies of resistance to $X$. campestris pv. campestris, which were mainly concerned with $B$. oleracea, identified cabbage cultivars with varying levels of field resistance $(1,7)$. Bain (3) made resistant selections from cabbage cvs. Huguenot and Early Fuji. The inheritance of resistance in cv. Early Fuji and derived lines was shown to be controlled by a recessive gene with modifiers (31) or quantitative trait loci (QTL) (5). Hunter et al. (14) showed that the cabbage accession PI 436606 expressed resistance in both seedlings and adult plants. Resistance at the seedling stage was attributed to a single recessive gene (6). Both Early Fuji and PI 436606 have been used in B. oleracea breeding programs. Several other studies have identified sources of resistance in $B$. oleracea $(13,23)$. However, despite the number of resistance studies in $B$. oleracea, available sources with useful levels of resistance are very limited.

Bain (2) reported that resistance to $X$. campestris pv. campestris was much more common in other Brassica spp. (B. nigra, B. napus, B. juncea, and B. rapa) than in B. oleracea. Guo et al. (12) found a high level of resistance in the accessions PI 199947 and PI 199949 (said by these authors to be B. napus) and a moderate level of resistance in two Chinese cabbage accessions (B. rapa). Westman et al. (29) identified a number of accessions of $B$. nigra

Corresponding author: J. G. Vicente; E-mail address: joana.vicente@ hri.ac.uk

Publication no. P-2001-1105-01R

(C) 2002 The American Phytopathological Society and B. juncea with a high proportion of resistant plants. A limitation of all these studies was their failure to recognize the existence of pathogenic variants (races) of X. campestris pv. campestris. Even with hindsight, it is not possible to determine the actual race type of the isolates used because, in many cases, the isolates were not specified or are no longer available and, in some cases, the authors used mixtures of isolates.

Since the first recognition of races of $X$. campestris pv. campestris by Kamoun et al. (17), there has been a clear need to define resistance in relation to the race type of the isolate or isolates used. Isolates of $X$. campestris pv. campestris were initially separated into five races (0 to 4 ) based on the reaction of cultivars of $B$. rapa and $B$. juncea (17). Recent reclassification of the race system into six races ( 1 to 6 ) was made on the basis of the reactions of an extended series of differential Brassica genotypes derived in part from the series of Kamoun et al. $(17,28)$. The current race structure is further defined on the basis of a gene-forgene relationship involving the postulated interactions of four matching gene pairs: avirulence (A) genes in the pathogen races and resistance $(\mathrm{R})$ genes in the differential hosts (Table 1). Of the currently defined races, only races 1 and 4 seem to be of major importance worldwide in B. oleracea, and races 2, 3, 5, and 6 are rare (28).

Recent studies using defined races identified race-specific resistance in accessions of $B$. oleracea, B. rapa, and B. napus $(15,16$, 20,22). However, not all races of $X$. campestris pv. campestris were used and there is some doubt as to the botanical identification of some of the resistant accessions.

This article presents information on the sources and origin of resistance to $X$. campestris pv. campestris in the economically important Brassica A, B, and C (rapa, nigra, and oleracea) genomes. The study uses known races of the pathogen and the postulated gene-for-gene relationship between pathogen and host to define types of resistance (race-specific and potential race-nonspecific resistance) and possible homologies of resistance genes within and between genomes. Some preliminary results of this study were previously reported (27). 


\section{MATERIALS AND METHODS}

Plant material and bacterial isolates. Initially, a selection of 70 accessions from a $B$. oleracea core collection (4) representing a range of crop types and ecogeographical origins held at the Horticulture Research International Genetic Resources Unit (HRIGRU), Wellesbourne, UK, was tested with eight isolates of $X$. campestris pv. campestris, including the designated type strains of the six races (Table 2). One plant was tested per isolate. In follow-up tests, 106 accessions, including 25 lines of cauliflower, 15 other $B$. oleracea lines (including some doubled haploid lines and lines previously considered resistant), and 66 other Brassicaceae accessions representing the most important genomes, mainly from the HRIGRU, were tested with the type strains of five $X$. campestris pv. campestris races (omitting race 2). Three plants were tested per isolate. Finally, 100 Brassica accessions from the HRIGRU, other gene banks, and commercial sources were tested with isolates of race 1 (HRI 3811), race 4 (HRI 1279A), and race 6 (HRI 6181). Three plants were inoculated per isolate.

Flow cytometry tests to determine DNA content as a guide to ploidy and chromosome number were performed according to a routine protocol (10) by G. Geenen (Plant Cytometry Services, Europalaan 74, 5481 JG Schijndel, Netherlands). This information was used as an aid to the botanical identification of the accessions. A total of 141 accessions was tested, together with known representative accessions of the six most important Brassica spp. ( $B$. oleracea, B. napus, B. rapa, B. juncea, B. nigra, and B. carinata), radish (Raphanus sativus), and white mustard (Sinapis alba). Additionally, a cytological examination of the chromosomes of microspores in Methaphase I and Anaphase I was performed by S. Armstrong (School of Biosciences, The University of Birmingham, UK) to confirm the new identification of a single accession.

Inoculations. Plants were raised from seed sown in 9-cmsquare plastic pots with Levington M2 compost (Scotts), in a glasshouse with a minimum temperature of 20 and $15^{\circ} \mathrm{C}$ (day and night), venting at 22 and $17^{\circ} \mathrm{C}$ (day and night), and supplementary lighting from October to March to give a 16-h photoperiod. Isolates were grown on King's medium B (18) at $30^{\circ} \mathrm{C}$ for $48 \mathrm{~h}$ before inoculation. Bacterial growth was scraped from the plates and suspended in $10 \mathrm{ml}$ of sterile tap water or saline solution $(0.85 \%$ $\mathrm{NaCl}$ ) to produce a suspension containing $10^{8}$ to $10^{9} \mathrm{CFU} / \mathrm{ml}$. Four-week-old plants were inoculated by clipping the secondary veins near the leaf margins with mouse-tooth forceps with the teeth wrapped in absorbent cotton wool and dipped in the bacterial suspension. In all, 10 to 12 points were inoculated per leaf and the three youngest leaves were inoculated per plant. The number of points inoculated, the number of points showing symptoms, and the severity of symptoms (assessed on a 0-to-3 scale based on the relative size of the largest lesion on each leaf) were recorded for each leaf 2 and 3 weeks after inoculation (28). A disease index obtained by multiplying the score by the proportion of infected points was calculated for each plant. Generally, plants without lesions or with a few small lesions (disease index $\leq 0.1$ ) were considered strongly resistant and plants with only small lesions or with less than one-quarter of points infected $(0.1<$ disease index $\leq$ 0.75 ) were considered partially resistant. All other plants, with more extensive lesions, were considered susceptible.

\section{RESULTS}

Screening for resistance to $X$. campestris pv. campestris in B. oleracea. The results of tests of the 70 accessions making the subset from the $B$. oleracea core collection, inoculated with eight isolates representing the six $X$. campestris pv. campestris races, are presented in Table 3. Half the accessions were susceptible to all races. None of the accessions showed evidence of strong resistance, but partial resistance to races 2,6 , or both was frequent (36\% of the accessions). Ten accessions showed partial resistance to races 3 or 5 . No resistance was found to races 1 and 4.

TABLE 1. Postulated gene-for-gene model to explain the relationship between Brassica cultivars and races of Xanthomonas campestris pv. campestris (28) ${ }^{\mathrm{a}}$

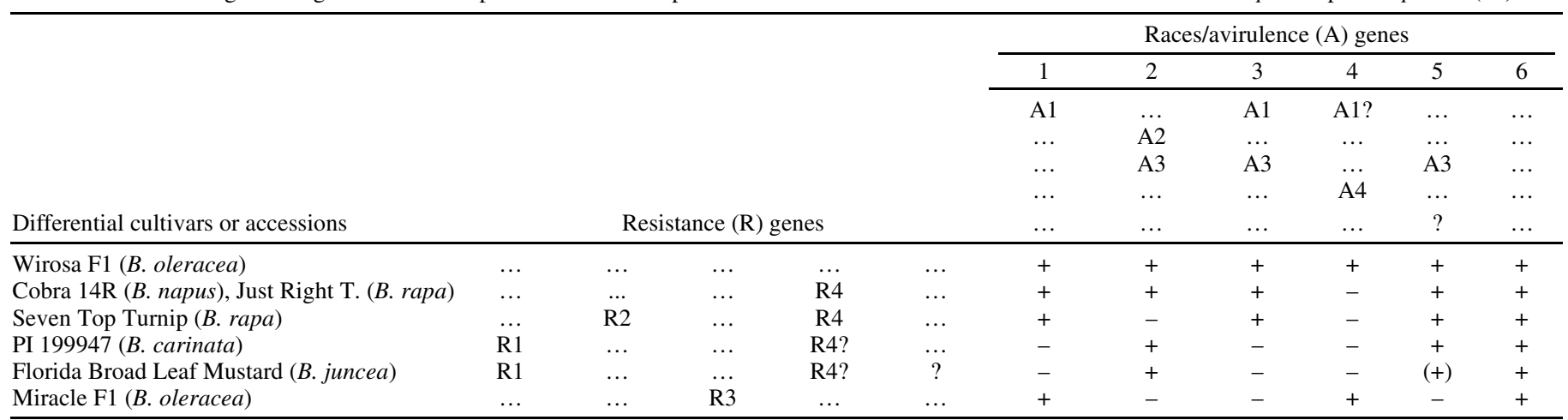

${ }^{\mathrm{a}}+=$ compatible interaction (susceptibility), $-=$ incompatible interaction (resistance), $(+)=$ weakly pathogenic, and $?=$ gene possible, but not certain.

TABLE 2. Xanthomonas campestris pv. campestris isolates used in this study

\begin{tabular}{|c|c|c|c|c|}
\hline Isolate number & Source (original designation) & Host & Country & Race \\
\hline $3811^{\mathrm{a}}$ & P. Williams (PHW1205) b & Brassica oleracea & United States & 1 \\
\hline $5212^{\mathrm{a}}$ & NCPPB $(528)^{e}$ & B. oleracea var. botrytis & United Kingdom & 3 \\
\hline $1279 A^{a}$ & $\ldots$ & B. oleracea var. capitata & United Kingdom & 4 \\
\hline $3880^{\mathrm{a}}$ & $\operatorname{NCPPB}(2986)$ & B. oleracea var. capitata & Australia & 5 \\
\hline $3883^{\mathrm{c}}$ & NCPPB (1946) & Raphanus sativus & United States & 5 \\
\hline $6181^{\mathrm{a}}$ & $\ldots$ & B. rapa & Portugal & 6 \\
\hline
\end{tabular}

${ }^{a}$ Race type strains of the six $X$. campestris pv. campestris races (28).

${ }^{\mathrm{b}}$ University of Wisconsin, Madison.

${ }^{c}$ Only used in the B. oleracea core collection screening.

${ }^{\mathrm{d}}$ University of California, Davis.

e NCPPB, National Collection of Plant Pathogenic Bacteria, Sand Hutton, UK.

${ }^{\mathrm{f}}$ Institute of Botany and Botanical Garden, University of Vienna, Austria. 
Screening for resistance to $X$. campestris pv. campestris in Brassicaceae genomes. The results of tests of 106 accessions representing eight Brassicaceae spp. inoculated with isolates of five races of $X$. campestris pv. campestris are presented in Table 4. Examples of the range of resistance responses shown by selected accessions of each of the species are shown in Table 5. A high proportion of the accessions gave variable reactions, including both resistant and susceptible plants. Of the B. oleracea accessions (e.g., cv. Wirosa F1), 58\% were susceptible to all races. Several cauliflower cultivars and lines of $B$. oleracea were resistant to races 3,5, or 6. The cauliflower hybrid Miracle F1 and a double haploid line $(\mathrm{BOH} 85 \mathrm{c})$ derived from the cabbage landrace Böhmerwaldkohl were uniformly resistant to races 3 and 5, whereas several Cornish cauliflower landraces showed variable resistance to these races, indicating that they were mixtures of genotypes. The cabbage line Badger Inbred 16 derived from cv. Early Fuji was the only B. oleracea accession tested that showed partial resistance to race 1 (Table 5).

The majority of the $B$. napus and $B$. rapa accessions (e.g., cvs. Couve nabiça and Lincolnshire Red Globe) were resistant to race 4 (Tables 4 and 5). Some of these accessions (e.g., the B. napus selection BR96068) also showed variable resistance to race 3, indicating a mixture of genotypes (Table 5). Two B. rapa accessions (e.g., cv. Broccoletto di rapa Natalino) appeared to be either resistant or partially resistant to all races.

Accessions of $B$. juncea and B. nigra were either resistant to all races (potential race-nonspecific resistance) or resistant to races 1 , 3,4 , and in some cases 5; there were no uniformly susceptible accessions. Accessions of $B$. carinata were either susceptible to all races or resistant to some races. Two accessions (e.g., cv. Patu) were partially resistant to all races. Among non-Brassica accessions, the white mustard (Sinapis alba) accessions tested were uniformly susceptible to all races, but some resistance was found in radish (Raphanus sativus) accessions (Tables 4 and 5).

Fifty-eight accessions were tested by flow cytometry to aid botanical identification. Based on these results and on morphological observations, five accessions were reidentified. One of these accessions, PI 199947, originally identified as B. napus (12), was reidentified as a $B$. carinata. A cytological examination of microspores of PI 199947 also showed a chromosome number $(n=17)$ consistent with it being a $B$. carinata accession.

Targeted screening for resistance to $X$. campestris pv. campestris races 1, 4, and 6 . The results of tests on 100 accessions representing 15 Brassicaceae spp. inoculated with isolates of the three most important $X$. campestris pv. campestris races are presented in Table 6. Examples of the range of resistance responses shown by selected accessions are shown in Table 7. All the wild types of B. oleracea tested (e.g., HRIGRU 6849) were susceptible to the three races. Some other accessions of $B$. oleracea (crop types) and some closely related Brassica spp. showed partial resistance to race 6 . Resistance to race 4 was present in a high proportion of the B. napus and B. rapa accessions tested. Generally, the winter rape cultivars (e.g., Pronto) showed a high level of resistance to race 4, whereas the spring rape cultivars (e.g., Rebel), although also resistant, tended toward partial resistance. The $B$. rapa spring turnip rape cultivars (e.g., Arran) were generally susceptible to the three races. Four accessions of B. rapa (e.g., cv. Sessantina Testa Grossa) showed resistance to the three races (potential race-nonspecific resistance). Accessions of B. juncea (e.g., cvs. Southern Giant Curled and Ndakapuka) were either resistant to races 1 and 4 or to the three races (potential race-nonspecific resistance). Most accessions of B. nigra (e.g., HRIGRU 11089) showed resistance to races 1 and 4 , but susceptible plants were

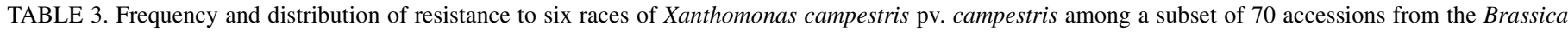
oleracea core collection

\begin{tabular}{|c|c|c|c|c|c|c|c|c|}
\hline \multirow[b]{2}{*}{ B. oleracea var. } & \multirow[b]{2}{*}{ Common name } & \multirow[b]{2}{*}{ No. susceptible ${ }^{a}$} & \multicolumn{5}{|c|}{ Number of accessions with resistance to race or races } & \multirow[b]{2}{*}{ Total tested } \\
\hline & & & 2 & 6 & 2 and 6 & 5 and $(2$ or 6$)$ & 3,5 , and $(2$ or 6$)$ & \\
\hline acephala & Kale & 1 & 2 & 0 & 2 & 4 & 1 & 10 \\
\hline alboglabra & Chinese kale & 2 & 0 & 0 & 0 & 0 & 0 & 2 \\
\hline botrytis & Cauliflower & 4 & 3 & 4 & 2 & 1 & 0 & 14 \\
\hline capitata & Cabbage & 9 & 2 & 0 & 2 & 1 & 1 & 15 \\
\hline gemmifera & Brussels sprouts & 6 & 0 & 0 & 0 & 0 & 0 & 6 \\
\hline gongylodes & Kohlrabi & 3 & 1 & 0 & 0 & 0 & 0 & 4 \\
\hline italica & Broccoli & 9 & 2 & 1 & 1 & 1 & 1 & 15 \\
\hline tronchuda & Tronchuda kale & 1 & 2 & 0 & 1 & 0 & 0 & 4 \\
\hline Total & $\ldots$ & 35 & 12 & 5 & 8 & 7 & 3 & 70 \\
\hline
\end{tabular}

a Number of accessions susceptible to all races.

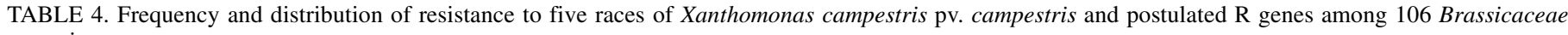
accessions

\begin{tabular}{|c|c|c|c|c|c|c|c|c|c|c|}
\hline \multirow[b]{2}{*}{ Species (genome) } & \multirow[b]{2}{*}{$\begin{array}{c}\text { No. } \\
\text { susceptible }^{\mathrm{a}}\end{array}$} & \multicolumn{8}{|c|}{ Number of accessions with resistance to race or races (postulated R genes) } & \multirow[b]{2}{*}{$\begin{array}{l}\text { Total } \\
\text { tested }\end{array}$} \\
\hline & & $\begin{array}{l}\text { All races } \\
\text { tested }\end{array}$ & $\begin{array}{c}1,3 \text {, and } 4 \\
\text { (R1) }\end{array}$ & $\begin{array}{c}1,3,4, \text { and } 5 \\
(\mathrm{R} 1+?)\end{array}$ & $\begin{array}{c}3 \text { and/or } 5 \\
(\mathrm{R} 3)\end{array}$ & $\begin{array}{c}3 \text { and/or } 5 \text { and } 6 \\
(\mathrm{R} 3+?)\end{array}$ & $\begin{array}{c}3 \text { and/or } 5 \text { and } 4 \\
(\mathrm{R} 3+\mathrm{R} 4)\end{array}$ & $\begin{array}{c}4 \\
(\mathrm{R} 4) \\
\end{array}$ & $\begin{array}{c}6 \\
(\mathrm{R} ?) \\
\end{array}$ & \\
\hline Brassica oleracea $(\mathrm{C})^{\mathrm{b}}$ & 10 & 0 & $1^{\mathrm{c}}$ & 0 & 2 & 2 & 0 & 0 & 0 & 15 \\
\hline B. oleracea $(\mathrm{C})^{\mathrm{d}}$ & 13 & 0 & 0 & 0 & 9 & 2 & 0 & 0 & 1 & 25 \\
\hline B. napus (AC) & 11 & 0 & 0 & 0 & 0 & 0 & 6 & 4 & 0 & 21 \\
\hline B. $\operatorname{rapa}(\mathrm{A})$ & 1 & 2 & 0 & 0 & 0 & 0 & 7 & 5 & 0 & 15 \\
\hline B. juncea (AB) & 0 & 4 & 2 & 2 & 0 & 0 & 0 & 0 & 0 & 8 \\
\hline B. nigra $(\mathrm{B})$ & 0 & 2 & 2 & 0 & 0 & 0 & 0 & 0 & 0 & 4 \\
\hline B. carinata $(\mathrm{BC})$ & 2 & 2 & 1 & 0 & 2 & 0 & 1 & 0 & 1 & 9 \\
\hline Sinapis alba & 4 & 0 & 0 & 0 & 0 & 0 & 0 & 0 & 0 & 4 \\
\hline Raphanus sativus & 0 & 0 & 0 & 0 & 2 & 1 & 2 & 0 & 0 & 5 \\
\hline Total & 41 & 10 & 6 & 2 & 15 & 5 & 16 & 9 & 2 & 106 \\
\hline
\end{tabular}

a Number of accessions susceptible to all races.

b Includes doubled haploid lines.

c Single accession (Badger Inbred-16) resistant to races 1, 3, 5, and 6.

${ }^{\mathrm{d}}$ Cauliflower hybrids and Cornish cauliflower landraces. 
also found in these accessions. Accessions of B. carinata were highly variable. One accession (HRIGRU 13160) showed partial resistance to the three races (potential race-nonspecific resistance).

Eighty-three accessions were tested by flow cytometry to aid botanical identification. Based on these results and on morphological characteristics, 10 accessions were reidentified. Four of these accessions (e.g., cv. Albatros) were received as B. juncea and were reidentified as Sinapis alba; these accessions were susceptible to the three races tested, contrasting with the $B$. juncea accessions, which were all resistant. Additionally, three accessions were shown to be mixtures of two species: BRA 1225/96 and HRIGRU 11104 were mixtures of $B$. carinata and $B$. rapa and HRIGRU 11084 was a mixture of $B$. carinata and $B$. nigra.

\section{DISCUSSION}

The genetic relationships among the cultivated Brassica spp. were established by Morinaga (19) and U (26). All the economically important species belong either in the three genomes $\mathrm{A}(B$. rapa), B (B. nigra), and C (B. oleracea), or in the amphidiploids derived from these genomes: $\mathrm{AB}$ (B. juncea), $\mathrm{AC}$ (B. napus), and $\mathrm{BC}$ (B. carinata) (21). One of the problems encountered in the present study was the incorrect botanical identification of a number of accessions. It has been shown that chromosome number in Brassicaceae can be estimated from measurement of DNA content with flow cytometry (9). Of the 276 Brassicaceae accessions screened for resistance to $X$. campestris pv. campestris races, the identity of 141 accessions was checked by flow cytometry and 15

TABLE 5. Selected examples of results obtained from the resistance screening of Brassicaceae accessions using five races of Xanthomonas campestris pv. campestris

\begin{tabular}{|c|c|c|c|c|c|c|c|c|c|}
\hline \multirow[b]{2}{*}{ Species } & \multirow[b]{2}{*}{ Name } & \multirow[b]{2}{*}{ Type $^{\mathrm{a}}$} & \multirow{2}{*}{$\begin{array}{c}\text { Source } \\
\text { (accession number) }\end{array}$} & \multicolumn{5}{|c|}{ Minimum and maximum disease index ${ }^{b}$} & \multirow{2}{*}{$\begin{array}{c}\text { Resistance } \\
\text { genes/uniformity }\end{array}$} \\
\hline & & & & Race 1 & Race 3 & Race 4 & Race 5 & Race 6 & \\
\hline Brassica oleracea & Wirosa F1 & Savoy cabbage; F1 & $\mathrm{Bejo}^{\mathrm{c}}$ & 3.0 & $2.5-3.0$ & $2.6-3.0$ & $1.9-3.0$ & $2.1-3.0$ & None/uniform \\
\hline B. oleracea & Böhmerwaldkohl & Cabbage; DH & D. Pink $(\mathrm{BOH} 85 \mathrm{c})^{\mathrm{d}}$ & $2.1-2.9$ & $\underline{0.2-0.6}$ & $1.8-2.2$ & $\underline{0.0-0.1}$ & $1.0-1.6$ & R3/uniform \\
\hline B. oleracea & Miracle F1 & Cauliflower; F1 & Bejo & $2.5-3.0$ & $0.1-0.5$ & $2.9-3.0$ & $\underline{0.1-0.5}$ & $0.9-1.7$ & R3/uniform \\
\hline B. oleracea & Cornish landraces & Cauliflower; OP & $\mathrm{HDC}^{\mathrm{e}}$ & $2.4-3.0$ & $\overline{0.3-3.0}$ & $2.7-3.0$ & $\overline{0.5-3.0}$ & $0.8-3.0$ & $\mathrm{R} 3 /$ mixture \\
\hline B. oleracea & Badger Inbred-16 & Cabbage; Ib & T. C. Osborne ${ }^{f}$ & $\underline{0.2-0.7}$ & $\overline{0.1}-0.2$ & $2.0-2.5$ & $\overline{0.1}$ & $\underline{0.3}$ & $\mathrm{R}$ ?/uniform \\
\hline B. napus & Crack & Rape; OP & HRIGRU (3354) & 3.0 & $\overline{2.7-3.0}$ & $2.7-3.0$ & $\overline{3.0}$ & $\overline{1.9}-2.6$ & None/uniform \\
\hline B. napus & Couve nabiça & Vegetable rape; OP & HRIGRU (9507) & $2.2-3.0$ & $0.9-2.1$ & $\underline{0.0}-2.7$ & $1.4-1.9$ & $0.8-2.8$ & R4/mixture \\
\hline B. napus & $\ldots$ & Rape; SPS & J. Walsh (BR96068) ${ }^{\mathrm{d}}$ & $1.0-1.1$ & $\underline{0.0-0.6}$ & $\overline{0.0}-0.2$ & $2.3-3.0$ & $1.4-2.6$ & $\mathrm{R} 4+\mathrm{R} 3 ?$ \\
\hline B. rapa & Mei Quing Choi & Pak Choi; F1 & HRIGRU (11270) & $2.1-2.8$ & $\overline{1.1-1.4}$ & $\overline{2.7-3.0}$ & $0.9-1.7$ & $1.8-2.3$ & None/uniform \\
\hline B. rapa & $\begin{array}{r}\text { Lincolnshire } \\
\text { Red Globe }\end{array}$ & Turnip; OP & HRIGRU (3433) & $2.0-3.0$ & $1.9-2.9$ & $\underline{0.0-0.2}$ & 3.0 & $2.3-3.0$ & R4/uniform \\
\hline B. rapa & $\ldots$ & Chinese cabbage; OP & USDA (PI 418984) & $1.3-2.7$ & $\underline{0.0}-2.5$ & $\underline{0.0}-2.8$ & $\underline{0.7-1.7}$ & $2.3-3.0$ & R4+R3?/mixture \\
\hline B. rapa & $\begin{array}{l}\text { Broccoletto di } \\
\text { rapa Natalino }\end{array}$ & Broccoletto; OP & HRIGRU (5235) & $\underline{0.1}-1.0$ & $\underline{\underline{0.1}}-2.0$ & $\overline{0.0}$ & $\overline{0.0}-0.7$ & $\underline{0.0}-1.9$ & $\begin{array}{l}\text { Race-nonspecific/ } \\
\text { mixture }\end{array}$ \\
\hline B. juncea & Covo & Indian mustard; OP & HRIGRU (4301) & $\underline{0.0}$ & $\underline{0.0}$ & $\underline{0.0}$ & $1.4-2.2$ & $1.0-2.0$ & R1/uniform \\
\hline B. juncea & Chotma & Indian mustard; OP & HRIGRU (3110) & $\underline{0.0-0.1}$ & $\underline{0.0}$ & $\underline{0.0}$ & $\underline{0.3}-0.9$ & $\underline{0.1-0.6}$ & $\begin{array}{l}\text { Race-nonspecific/ } \\
\text { mixture }\end{array}$ \\
\hline B. nigra & $\ldots$ & Black mustard; OP & HRIGRU (11076) & $\underline{0.0}-3.0$ & $\underline{0.0}-3.0$ & $\underline{0.0}-1.6$ & $2.4-2.6$ & $1.9-3.0$ & $\mathrm{R} 1 /$ mixture \\
\hline B. nigra & $\ldots$ & Black mustard; OP & HRIGRU (11069) & $\underline{0.0-0.2}$ & $\underline{0.0}$ & $\underline{0.0}$ & $\underline{0.0}$ & $\underline{0.4-1.7}$ & $\begin{array}{l}\text { Race-nonspecific/ } \\
\text { mixture }\end{array}$ \\
\hline B. carinata & $\ldots$ & Ethiopian mustard; SPS & USDA (PI 199947) & $\underline{0.0}$ & $\underline{0.0}$ & $\underline{0.0}$ & $1.1-1.4$ & $1.0-2.3$ & R1/uniform \\
\hline B. carinata & $\ldots$ & Ethiopian mustard; OP & USDA (PI 199949) & $\overline{0.8}-2.4$ & $\overline{0.6}-1.4$ & $\overline{1.4}-2.4$ & $\underline{0.1-0.3}$ & $2.4-2.8$ & R3?/mixture \\
\hline B. carinata & Patu & Ethiopian mustard; OP & HRIGRU (6232) & $\underline{0.0-0.1}$ & $\underline{0.2-0.5}$ & $\underline{0.0-0.3}$ & $\underline{0.0}$ & $\underline{0.1-0.4}$ & $\begin{array}{l}\text { Race-nonspecific/ } \\
\text { uniform }\end{array}$ \\
\hline Raphanus sativus & Dugansky & Radish; OP & HRIGRU (2377) & $2.5-2.8$ & $\underline{0.5}-0.9$ & $1.2-3.0$ & $\underline{0.2-0.7}$ & $1.4-1.9$ & $\mathrm{R} 3$ ?/mixture \\
\hline R. sativus & Rane & Radish; OP & HRIGRU (6337) & $1.7-2.1$ & $\underline{0.1}-0.2$ & $\underline{0.4-0.8}$ & $\underline{0.0-0.3}$ & $0.9-2.2$ & $\mathrm{R} 3 ?+\mathrm{R} 4 /$ mixture \\
\hline Sinapis alba & Santa Fe & White mustard; OP & HRIGRU (11984) & $2.6-2.9$ & $1.2-3.0$ & $1.4-3.0$ & $2.1-3.0$ & $2.2-3.0$ & None/uniform \\
\hline
\end{tabular}

${ }^{\mathrm{a}} \mathrm{F} 1=\mathrm{F} 1$ hybrid, $\mathrm{DH}=$ doubled haploid line, $\mathrm{OP}=$ open pollinated, and SPS = single plant selection derived from an open pollinated accession.

b Plants with a disease index $\leq 0.75$ (underlined) were considered resistant.

c Bejo Zaden b.v., Warmenhuizen, Holland.

${ }^{\mathrm{d}}$ Horticulture Research International, Wellesbourne, UK.

${ }^{\mathrm{e}} \mathrm{HDC}=$ Horticultural Development Council, UK.

${ }^{\mathrm{f}}$ University of Wisconsin, Madison.

g Horticulture Research International Genetic Resources Unit (HRIGRU), Wellesbourne, UK

${ }^{\mathrm{h}}$ United States Department of Agriculture-Agricultural Research Service, United States Plant Introduction Station collection.

TABLE 6. Frequency and distribution of resistance to three races of Xanthomonas campestris pv. campestris among 100 Brassicaceae accessions

\begin{tabular}{|c|c|c|c|c|c|c|}
\hline \multirow[b]{2}{*}{ Species (genome) } & \multirow[b]{2}{*}{ No. susceptible ${ }^{a}$} & \multicolumn{4}{|c|}{$\begin{array}{l}\text { Number of accessions with resistance to race or races } \\
\text { (postulated R genes) }\end{array}$} & \multirow[b]{2}{*}{ Total tested } \\
\hline & & All races tested & 1 and $4(\mathrm{R} 1)$ & $4(\mathrm{R} 4)$ & $6(\mathrm{R} ?)$ & \\
\hline Brassica oleracea-wild types (C) & 12 & 0 & 0 & 0 & 0 & 12 \\
\hline B. oleracea-crop types $(\mathrm{C})$ & 3 & 0 & 0 & 0 & 4 & 7 \\
\hline B. rupestris, B. incana, B. alboglabra, B. montana, & 5 & 0 & 0 & 0 & 3 & 8 \\
\hline 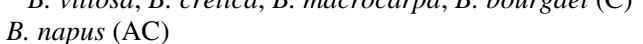 & $\begin{array}{l}5 \\
1\end{array}$ & 0 & $\begin{array}{l}0 \\
0\end{array}$ & $\begin{array}{r}0 \\
16\end{array}$ & $\begin{array}{l}3 \\
0\end{array}$ & $\begin{array}{r}8 \\
17\end{array}$ \\
\hline B. $\operatorname{rapa}(\mathrm{A})$ & 12 & 4 & 0 & 9 & 0 & 25 \\
\hline B. juncea (AB) & 0 & 9 & 2 & 0 & 0 & 11 \\
\hline B. nigra $(\mathrm{B})$ & 0 & 0 & 5 & 1 & 0 & 6 \\
\hline B. carinata $(\mathrm{BC})$ & 6 & 1 & 2 & 1 & 0 & 10 \\
\hline Sinapis alba & 4 & 0 & 0 & 0 & 0 & 4 \\
\hline Total & 43 & 14 & 9 & 27 & 7 & 100 \\
\hline
\end{tabular}

a Number of accessions susceptible to all races. 
were found to have been identified incorrectly. Patterns of resistance that were atypical for a particular genome (e.g., apparent resistance to race 4 in accessions purporting to be $B$. oleracea, or susceptibility in $B$. juncea) were shown to be due to misidentification. A detailed morphological examination together with flow cytometry can help in avoiding this problem in the future.

Most previous searches for resistance to X. campestris pv. campestris have concentrated on $B$. oleracea, mainly because of the high importance of the disease in horticultural brassicas (cabbage, cauliflower, Brussels sprouts, kale, and others). In the present study, we have attempted a broader evaluation of Brassica spp. including representatives of all the crop species, wild types of $B$. oleracea and other $\mathrm{C}$ genome species, and also other Brassicaceae genera (Raphanus and Sinapis). Screening was carried out in three stages. Initially, 70 accessions from the $B$. oleracea core collection were challenged with all six races of $X$. campestris pv. campestris to establish the extent and types of resistance in $B$. oleracea (Table 3 ). In the second stage, 106 accessions representative of other Brassica genomes and other Brassicaceae spp. were also included. In this case, accessions were challenged with five races, omitting race 2 , which is rare and of low pathogenicity (Table 4). In the third and final stage, screening was carried out on 100 accessions using only the three most important or potentially important races. Races 1 and 4 are currently the most widespread, and race 6 has the widest host range (28) (Table 6). The summarized results of all three stages, involving tests on the total 276 accessions, are shown in Table 8 .

All of the screening was performed in a glasshouse using a method (leaf clipping of young plants with a concentrated bacterial suspension) that clearly favors the pathogen and the rapid development of symptoms. This method might fail to identify accessions with low levels of resistance, possibly equivalent to field resistance. Another limitation was the small number of plants of each accession tested and the fact that each plant was only inoculated with a single race. Because of this, some of the accessions, considered to be uniform, could have undetected variability.

Screening results expressed as disease index (Tables 5 and 7) showed two main types of resistance. Race-specific resistance was

TABLE 7. Selected examples of results obtained from the resistance screening of Brassicaceae accessions using three races of Xanthomonas campestris pv. campestris

\begin{tabular}{|c|c|c|c|c|c|c|c|}
\hline \multirow[b]{2}{*}{ Species } & \multirow[b]{2}{*}{ Name } & \multirow[b]{2}{*}{ Type $^{\mathrm{a}}$} & \multirow{2}{*}{$\begin{array}{c}\text { Source } \\
\text { (accession number) }\end{array}$} & \multicolumn{3}{|c|}{ Minimum and maximum disease inde $\mathrm{x}^{\mathrm{b}}$} & \multirow{2}{*}{$\begin{array}{c}\text { Resistance } \\
\text { genes/uniformity }\end{array}$} \\
\hline & & & & Race 1 & Race 4 & Race 6 & \\
\hline Brassica oleracea & $\ldots$ & Wild furry cabbage; OP & HRIGRU $(6849)^{\mathrm{c}}$ & $2.8-3.0$ & $2.8-3.0$ & 2.9 & None/uniform \\
\hline B. bourgaei & $\ldots$ & $\ldots$ & D. Pink (CA97009) ${ }^{\mathrm{d}}$ & $2.3-2.7$ & $2.3-3.0$ & $0.1-0.8$ & $\mathrm{R} ? /$ mixture \\
\hline B. napus & Pronto & Winter oilseed rape; RH & CPB Twyford & $2.0-2.2$ & 0.0 & $1.0-1.6$ & R4/uniform \\
\hline B. napus & Rebel & Spring oilseed rape; OP & Dalgety ${ }^{\mathrm{f}}$ & $2.4-3.0$ & $\overline{0.3}-0.7$ & $0.9-1.1$ & R4/uniform \\
\hline B. rapa & Arran & Spring turnip rape; OP & Semundog & $2.6-3.0$ & $2.5-3.0$ & $2.5-3.0$ & None/uniform \\
\hline B. rapa & Jhao & Turnip; OP & HRIGRU (3119) & 3.0 & $\underline{0.0}$ & $2.9-3.0$ & R4/uniform \\
\hline B. rapa & $\begin{array}{l}\text { Sessantina } \\
\text { Testa Grossa }\end{array}$ & Broccoletto; OP & HRIGRU (4714) & $\underline{0.2-0.5}$ & $\overline{0.0}-1.9$ & $\underline{0.0}-3.0$ & $\begin{array}{l}\text { Race-nonspecific/ } \\
\text { mixture }\end{array}$ \\
\hline B. juncea & $\begin{array}{l}\text { Southern } \\
\text { Giant Curled }\end{array}$ & Mustard; OP & Twilley Seeds ${ }^{\mathrm{h}}$ & $\underline{0.0}$ & $\underline{0.0}$ & $1.1-1.3$ & R1/uniform \\
\hline B. juncea & Ndakapuka & Indian mustard; OP & HRIGRU (4273) & $\underline{0.0-0.1}$ & $\underline{0.0-0.2}$ & $\underline{0.3}-0.8$ & $\begin{array}{l}\text { Race-nonspecific/ } \\
\text { mixture }\end{array}$ \\
\hline B. nigra & $\ldots$ & Black mustard; OP & HRIGRU (11089) & $\underline{0.3}-3.0$ & $\underline{0.0}-3.0$ & $2.7-3.0$ & $\mathrm{R} 1 /$ mixture \\
\hline B. carinata & $\ldots$ & Ethiopian mustard; OPMS & HRIGRU (11084) & $\overline{0.9}-2.2$ & $\overline{2.0}-2.6$ & $1.7-2.0$ & None/uniform \\
\hline B. carinata & $\ldots$ & Ethiopian mustard; OPMS & HRIGRU (11104) & $\underline{0.0}-1.3$ & $\underline{0.0}-1.3$ & $1.2-2.5$ & $\mathrm{R} 1 /$ mixture \\
\hline B. carinata & $\cdots$ & Ethiopian mustard; OP & HRIGRU (13160) & $\overline{0.1}-0.3$ & $\underline{0.5}-1.1$ & $\underline{0.2-1.0}$ & $\begin{array}{l}\text { Race-nonspecific/ } \\
\text { mixture }\end{array}$ \\
\hline Sinapis alba & Albatros & White mustard; OP & USDA $(G 31961)^{\mathrm{i}}$ & $1.0-2.8$ & $2.6-2.7$ & $1.4-2.7$ & None/uniform \\
\hline
\end{tabular}

a $\mathrm{OP}=$ open pollinated, $\mathrm{RH}=$ restored hybrid, OPMS = open pollinated accession with two mixed species.

${ }^{\mathrm{b}}$ Plants with a disease index $\leq 0.75$ (underlined) were considered resistant.

c Horticulture Research International Genetic Resources Unit (HRIGRU), Wellesbourne, UK.

d Horticulture Research International, Wellesbourne, UK.

e CPB Twyford, Hertfordshire, UK.

f Dalgety Agriculture Ltd., Essex, UK.

g Semundo Limited, Great Abingdon, UK.

h Ottis S. Twilley Seed Co. Inc., Hodges, SC.

i United States Department of Agriculture-Agricultural Research Service, United States Plant Introduction Station collection.

TABLE 8. Summary of frequency and distribution of resistance types (potential race-nonspecific and race-specific with postulated R-genes) among 276 Brassicaceae accessions

\begin{tabular}{|c|c|c|c|c|}
\hline \multirow[b]{2}{*}{ Species (genome) } & \multicolumn{3}{|c|}{ Number of accessions } & \multirow[b]{2}{*}{ Total tested } \\
\hline & Sus. to all ${ }^{\mathrm{a}}$ & Res. to all ${ }^{\mathrm{b}}$ & Res. to some (postulated R genes) ${ }^{\mathrm{c}}$ & \\
\hline Brassica oleracea $(\mathrm{C})$ & 73 & 0 & 56 (R3, R?) & 129 \\
\hline B. $\operatorname{rapa}(\mathrm{A})$ & 13 & 6 & $21(\mathrm{R} 3 ?, \mathrm{R} 4)$ & 40 \\
\hline B. juncea (AB) & 0 & 13 & 6 (R1 and R4?) & 19 \\
\hline B. nigra (B) & 0 & 2 & 8 (R1) & 10 \\
\hline Raphanus sativus & 0 & 0 & 5 (R3, R4) & 5 \\
\hline Total & 119 & 24 & 133 & 276 \\
\hline Percentage & 43 & 9 & 48 & $\ldots$ \\
\hline
\end{tabular}

${ }^{a}$ Susceptible to all races.

b Resistant to all races (race-nonspecific resistance?).

${ }^{\mathrm{c}}$ Resistant to some races. 
the most common and was present in $48 \%$ of all accessions tested. In most cases, race-specific resistance was expressed as a strong reaction (disease index 0.0 to 0.1 ), but partial resistance (disease index 0.2 to 0.75 ) was also observed, especially in B. oleracea. Resistance to all races (potential race-nonspecific resistance) was less common and was present in $9 \%$ of accessions tested. This appeared to be restricted to the A and B genomes.

In the case of strong race-specific resistance, the likely resistance $(\mathrm{R})$ genes involved were deduced from comparison with the responses of the differential cultivars in the postulated gene-forgene model of Vicente et al. (28) (Table 1). This resistance could mainly be explained on the basis of three R genes (R1, R3, and R4).

Resistance to races 3 and 5 was common in B. oleracea, especially in cauliflower, and is probably controlled by the R3 gene. Ignatov et al. (15) also identified B. oleracea accessions with resistance to race 3 (designated race 1 by these authors).

Resistance to race 4 (but not race 1) was most common in $B$. rapa (A genome) and $B$. napus (AC genome), which suggests an A genome origin. This resistance is probably controlled by the R4 gene. Other authors have also found resistance to race 4 in these genomes $(16,20,22)$. In addition, we found variable resistance to races 3 and 5 in B. rapa and B. napus. This resistance could be due to R3, but is more likely to be controlled by a different gene. The genus Raphanus shares a common ancestry and has close chromosome homology with $B$. rapa and B. oleracea (11). Therefore, the resistance found in $R$. sativus could also be controlled by R3 and R4.

Resistance to races 1,3 , and 4 was found in B. nigra (B genome), B. carinata (BC genome), and B. juncea (AB genome), which suggests a B genome origin. This resistance is probably controlled either by R1 or R1 and R4, although other genes could also be involved. Some susceptible plants were found as mixtures in accessions of $B$. nigra and $B$. carinata, but accessions of $B$. juncea were uniformly resistant. This may be due to a combination of genes, R1 from the B genome and R4 from the A genome. Resistance gene R2 was not detected. However, R2, which is postulated to be present in the A genome (cv. Seven Top Turnip) (Table 1), can only be detected by inoculation with race 2 . Race 2 was omitted from all tests on the A and B genomes; therefore, the true incidence of R2 is unknown.

Not all observed resistances can be attributed to the four postulated major disease resistance genes (R1 to R4). In B. oleracea (and other $\mathrm{C}$ genome species) some accessions showed partial resistance to races 2 and 6 (R?), but these races appear to be generally weaker in their pathogenicity to $B$. oleracea. Partial resistance to races $1,3,5$, and 6 (a unique pattern of resistance) was present only in the line Badger Inbred 16, derived from cv. Early Fuji. Camargo et al. (5) attributed the control of this resistance to QTL. The resistance of Badger Inbred 16 is clearly different from that conferred by $\mathrm{R} 1$, which gives strong resistance to races 1,3 , and 4 .

The existence of genes R1, R3, and R4 was first postulated on the basis of the gene-for-gene model, but without genetic proof. Recent inheritance studies by J. G. Vicente, J. D. Taylor, A. G. Sharpe, I. A. P. Parkin, D. J. Lydiate, and G. J. King (unpublished data) have confirmed that each is a single dominant gene. Further evidence on the occurrence and distribution of these genes in the present study clearly supports their origin: R1 from the B genome, $\mathrm{R} 3$ from the $\mathrm{C}$ genome, and $\mathrm{R} 4$ from the A genome.

The identification of potentially race-nonspecific resistance in the $\mathrm{A}$ and the $\mathrm{B}$ genomes was possibly the most interesting finding of this study. This resistance was distinguished from that conferred by R1 or R1 and R4, particularly by the response to race 6 . Similar race-nonspecific resistance has been found with bacterial pathogens of leguminous hosts (Pseudomonas syringae pv. phaseolicola in beans and $P$. syringae pv. pisi in peas). In these cases, race-nonspecific resistance was due to recessive genes $(8,25)$. It has been suggested that, for peas and beans, durable resistance might be achieved by the combination of race-specific resistance and race-nonspecific resistance (24). A similar strategy for durable resistance to $X$. campestris pv. campestris in B. oleracea would involve the deployment of R1 and possibly R4 together with racenonspecific resistance. The practicality of transference of resistance through interspecific crosses or transformation of R1 and race-nonspecific resistance from the $\mathrm{B}$ genome and $\mathrm{R} 4$ and racenonspecific resistance from the A genome would be the main determinant of breeding strategy.

\section{ACKNOWLEDGMENTS}

This work was supported by the Ministry of Agriculture, Fisheries, and Food (MAFF) and the Biotechnology and Biological Research Council (BBSRC). Part of the work of J. Vicente was supported by a grant from PRAXIS XXI (ref. BD/3780/94). We thank S. Armstrong from the University of Birmingham, School of Biosciences, for the cytological examination of PI 199947; the Horticultural Development Council (HDC) for permission to publish results of tests on Cornish cauliflowers; D. Pink and J. Walsh from Horticulture Research International for the supply of some accessions and information; P. Welch for plant inoculations; and seed companies CPB Twyford, Dalgety, Danisco, Perryfields, Nickersons, and Semundo for the supply of oilseed rape and turnip rape cultivars.

\section{LITERATURE CITED}

1. Bach, W. J., and Taubenhaus, J. J. 1930. Black rot of cabbage and its control. Tex. Agric. Exp. Stn. Bull. 57:3-10.

2. Bain, D. C. 1952. Reaction of Brassica seedlings to black rot. Phytopathology 42:497-500.

3. Bain, D. C. 1955. Resistance of cabbage to black rot. Phytopathology 45:35-37.

4. Boukema, I. W., van Hintum, T. J. L., and Astley, D. 1997. Creation and composition of the Brassica oleracea core collection. Plant Genet. Resour. Newsl. 111:29-32.

5. Camargo, L. E. A., Williams, P. H., and Osborn, T. C. 1995. Mapping of quantitative trait loci controlling resistance of Brassica oleracea to Xanthomonas campestris pv. campestris in the field and greenhouse. Phytopathology 85:1296-1300.

6. Dickson, M. H., and Hunter, J. E. 1987. Inheritance of resistance in cabbage seedlings to black rot. HortScience 22:108-109.

7. Edwards, S. F. 1908. Cabbage resistance to black rot. Ontario Agric. Coll. Annu. Rep. 33:134.

8. Elvira-Recuenco, M., Ellis, T. H. N., and Taylor, J. D. 2000. Inheritance of race non-specific resistance to Pseudomonas syringae pv. pisi derived from Pisum abyssinicum and molecular markers for resistance. Pages 3967 in: Sustainable Control of Pea Bacterial Blight. Approaches For Durble Genetic Resistance and Biocontrol by Endophytic Bacteria. Ph.D. thesis. University of Wageningen, The Netherlands.

9. Fahleson, J., Dixelius, J., Sundberg, E., and Glimelius, K. 1988. Correlation between flow cytometric determination of nuclear DNA conent and chromosome number in somatic hybrids within Brassicaceae. Plant Cell Rep. 7:74-77

10. Geenen, G. 1993. Flowcytometric DNA analysis for determination of ploidy levels in lily. Pages 70-77 in: The Lily Yearbook of the North American Lily Society (for 1990). The North American Lily Society. Owatonna, MN.

11. Gómez-Campo, C., and Prakash, S. 1999. Origin and domestication. Pages 33-58 in: Biology of Brassica Coenospecies. C. Gómez-Campo, ed. Elsevier, Amsterdam.

12. Guo, H., Dickson, M. H., and Hunter, J. E. 1991. Brassica napus sources of resistance to black rot of crucifers and inheritance of resistance. HortScience 26:1545-1547.

13. Henz, G. P., Reifschneider, F. J. B., Takatsu, A., and Giordano, L. B. 1987. Identificação de fontes de resistência a Xanthomonas campestris pv. campestris em Brássicas. Hortic. Bras. 5:18-20.

14. Hunter, J. E., Dickson, M. H., and Ludwig, J. 1987. Source of resistance to black rot of cabbage expressed in seedlings and adult plants. Plant Dis. 71:263-266.

15. Ignatov, A., Kuginuki, Y., and Hida, K. 1998. Race-specific reaction of resistance to black rot in Brassica oleracea. Eur. J. Plant Pathol. 104:821-827.

16. Ignatov, A., Kuginuki, Y., and Hida, K. 2000. Distribution and inheritance of race-specific resistance to Xanthomonas campestris pv. campestris in Brassica rapa and B. napus. J. Russ. Phytopathol. Soc. 1:89-94. 
17. Kamoun, S., Kamdar, H. V., Tola, E., and Kado, C. I. 1992. Incompatible interactions between crucifers and Xanthomonas campestris involve a vascular hypersensitive response: Role of the hrpX locus. Mol. PlantMicrobe Interact. 5:22-23.

18. King, E. O., Ward, M. K., and Raney, D. R. 1954. Two simple media for the demonstration of pyrocanin and fluorescin. J. Lab. Clin. Med. 44:301-307.

19. Morinaga, T. 1934. Interspecific hybridization in Brassica. VI. The cytology of $\mathrm{F}_{1}$ hybrids of B. juncea and B. nigra. Cytologia 6:62-67.

20. Nogueira, A. P., and Dias, J. S. 1997. Screening of a Brassica rapa collection with two Portuguese isolates of Xanthomonas campestris pv. campestris. Page 211 in: ISHS Symp. Brassicas, 10th Crucifer Genet. Workshop, Rennes, France.

21. Prakash, S., Takahata, Y., Kirti, P. B., and Chopra, V. L. 1999. Cytogenetics. Pages 59-106 in: Biology of Brassica Coenospecies. C. Gómez-Campo, ed. Elsevier, Amsterdam.

22. Ribeiro, B., and Dias, J. S. 1997. Screening of a Brassica napus collection with two Portuguese isolates of Xanthomonas campestris pv. campestris. Page 210 in: ISHS Symp. Brassicas, 10th Crucifer Genet. Workshop, Rennes, France.

23. Sharma, B. R., Swarup, V., and Chatterjee, S. S. 1977. Resistance to black rot disease (Xanthomonas campestris (Pam.) Dowson, in cauliflower. Sci. Hortic. 7:1-7.
24. Taylor, J. D., Teverson, D. M., and Davis, J. H. C. 1996. Sources of resistance to Pseudomonas syringae pv. syringae races in Phaseolus vulgaris. Plant Pathol. 45:479-485.

25. Teverson, D. M. 1991. Genetics of pathogenicity and resistance in the halo-blight disease of beans in Africa. Ph.D. thesis. University of Birmingham, U.K

26. U, N. 1935. Genome analysis in Brassica with special reference to the experimental formation of $B$. napus and peculiar mode of fertilization. Jpn. J. Bot. 7:389-452.

27. Vicente, J. G., Conway, J., King, G. J., and Taylor, J. D. 2000. Resistance to Xanthomonas campestris pv. campestris in Brassica spp. Acta Hortic. 539:61-67.

28. Vicente, J. G., Conway, J., Roberts, S. J., and Taylor, J. D. 2001. Identification and origin of Xanthomonas campestris pv. campestris races and related pathovars. Phytopathology 91:492-499.

29. Westman, A. L., Kresovich, S., and Dickson, M. H. 1999. Regional variation in Brassica nigra and other weedy crucifers for disease reaction to Alternaria brassicicola and Xanthomonas campestris pv. campestris. Euphytica 106:253-259.

30. Williams, P. H. 1980. Black rot: A continuing threat to world crucifers. Plant Dis. 64:736-742.

31. Williams, P. H., Staub, T., and Sutton, J. C. 1972. Inheritance of resistance in cabbage to black rot. Phytopathology 62:247-252. 